\title{
Rancang Bangun Alat Roll Press Untuk Mengolah Batang Tanaman Rumput Payung (Cyperus Alternifolius) Menjadi Serat Bahan Baku Komposit
}

\author{
Danang Murdiyanto, Nereus Tugur Redationo \\ Universitas Katolik Widya Karya, Jl. Bondowoso no.2 Malang \\ 0341553171 \\ E-mail: danang_t.mesin@widyakarya.ac.id
}

\begin{abstract}
Composite material could be developed into new material that would be useful for many interests. Fiber as composite raw material must be given pretreatment to improve the quality of composite. In this research, raw material for the composite was umbrella grass (Cyperus Alternifolius). A tool was designed to facilitate the processes of rolling or pressing, or abbreviated as roll press. Indeed, the design of roll press was preceded by designing the construction section that involved shaft, transmission system, bearing, pulley belt, and driver motor to move the roll. Result of rolling must be suitable for processing umbrella grass into the fiber of composite raw material. Testing was conduced to examine the work of the tool against the stalk of umbrella grass. Two testing was considered. First was testing against the variation of loads, which involved $10 \mathrm{~kg}, 12 \mathrm{~kg}$ and $14 \mathrm{~kg}$. Second test was against the variation of roll rotation at 160rpm, 197rpm and $280 \mathrm{rpm}$. Result of both tests provided specific fiber derived from umbrella grass that would be compatible to be composite material. Some results of research were indicated. Main drive motor was $1 / 2$ PK with rotation $\left(n_{1}\right)=1430 \mathrm{rpm}$. Pulley diameter $\left(d_{1}\right)$ was $75 \mathrm{~mm}$. Reducer system was signified by $n_{2}=831 \mathrm{rpm}$ and $d_{2}=129 \mathrm{~mm}$, and if $d_{3}=59 \mathrm{~mm}$ was used, the outcome was $n_{4}$ $=160 \mathrm{rpm}$ with $d_{4}=307 \mathrm{~mm}$. In case of bearing, its sliding moment was $0.309 \mathrm{~N} . \mathrm{mm}$ and tangent force was $2.06 \mathrm{~N}$. The frame of roll press tool was designed at the dimension of length $x$ wide $x$ height $=600 \mathrm{~mm} \times 320 \mathrm{~mm} \times 1200 \mathrm{~mm}$. The best parameter was $160 \mathrm{rpm}$ with load force of $10 \mathrm{~kg}$. By taking account all these results, it could be said that the result of roll press processing had successfully produced the fiber from umbrella grass into the suitable raw material for the composite.
\end{abstract}

Keywords: roll press, grass umbrellas, fiber, construction, composites.

\section{PENDAHULUAN}

Pada saat ini perkembangan teknologi bahan semakin maju dan kreatif. Faktor utama yang mempengaruhi satunya yaitu kebutuhan akan bahan dengan karakteristik tertentu. Kebutuhan bahan tersebut salah satunya dikembangkan dalam bentuk bahan komposit. Kemampuan bahan komposit ini mudah dibentuk sesuai dengan kebutuhan dalam segi kekuatan, bentuk, dan keunggulannya dalam rasio kekuatan terhadap berat. Kelebihan material komposit dibandingkan dengan material berbahan baku logam adalah ketahanan terhadap korosi atau pengaruh lingkungan bebas dan untuk jenis komposit tertentu memiliki kekuatan dan kekakuan yang lebih baik.
Dalam penelitian ini, peneliti akan memanfaatkan tanaman rumput payung (cyperus alternifolius) sebagai bahan baku utama yang akan digunakan sebagai filler. Tanaman rumput payung merupakan tanaman tropis yang tumbuh subur dan banyak didapati di daerah yang lembab dan banyak air. Tanaman ini biasa dimanfaatkan sebagai tanaman hias. Permasalahan muncul dengan mempertimbangkan bahwa rumput payung mempunyai sifat berkembang biak dengan cepat sehingga menghasilkan banyak limbah. $\mathrm{Di}$ sisi lain serat batangnya ternyata mempunyai kekuatan mekanik yang baik, maka dari itu peneliti mengangkat tentang mendesain roll press yang digunakan untuk proses pengolahan batang tanaman rumput payung 
(cyperus alternifolius) sebagai bahan baku utama (filler) komposit berupa serat (fiber). Sehingga diharapkan akan memudahkan bahan yang berupa serat untuk diproses ke tahap selanjutnya pada pembentukan bahan komposit.

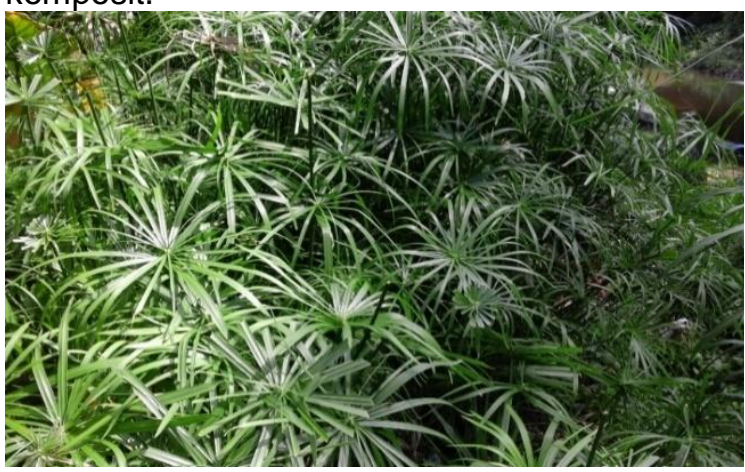

Gambar 1. Tanaman rumput payung (Cyperus Alternifolius)

Berdasarkan latar belakang di atas, peneliti akan membuka peluang pemanfaatan batang tanaman rumput payung (cyperus alternifolius) dengan menyelesaikan beberapa permasalahan mendasar yaitu: desain roll press untuk pengolah batang rumput payung menjadi serat sebagai bahan utama (filler) komposit. Untuk melakukan tahap desain roll press tersebut maka dibagi beberapa target penelitian yaitu: (1) desain kontruksi, (2) kapasitas dan (3) daya penggerak. Ketiga pembahasan tersebut dipilih dengan pertimbangan untuk optimalisasi produksi serat sebagai bahan baku komposit.

Tujuan penelitian berdasarkan permasalah yang ada adalah (1) menentukan desain dan kemampuan produksi roll press untuk membuat serat sebagai bahan komposit. (2) menentukan dimensi ketebalan serat yang dihasilkan sebagai bahan utama (filler).

Adapun target luaran pada penelitian ini yaitu: perhitungan desain roll press dan pemilihan material, optimalisasi hasil produk serat rumput payung.

\section{METODOLOGI PENELITIAN}

Pada penelitian ini, langkah-langkah yang dilakukan dalam pembuatan rancang bangun alat roll press batang tanaman rumput payung (Cyperus Alternifolius) ini dilakukan denngan beberapa tahap antara lain dapat dilihat pada gambar diagram alir metode penelitian dibawah ini.

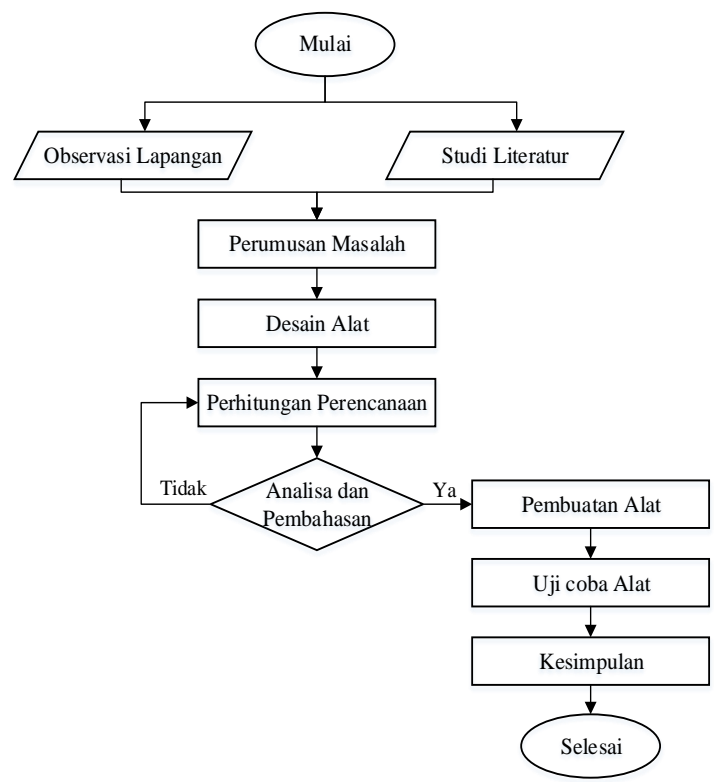

Gambar 2. Diagram alir metode penelitian

Proses pengerjaan merupakan urutan langkah pengerjaan dari bahan baku sampai menjadi benda kerja sesuai dengan ukuran yang telah direncanakan. Di dalam pengerjaan harus memperhatikan efisiensi yang berfungsi sebagai petunjuk dalam membuat suatu komponen. Adapun langkah-langkah yang dilakukan dalam penelian berdasarkan diagram alir metode penelitian yang digunakan adalah sebagai berikut:

1. Observasi lapangan da Studi literatur

Langkah awal dari penelitian ini adalah melakukan observasi, observasi dalam penelitian ini dilakukan guna untuk mengumpulkan data-data yang dibutuhkan dalam melakukan perencanaan dan pembuatan roll press batang rumput payung. Data-data tersebut akan diolah dengan mengacu pada studi literatur, sehingga akan sangat membantu dalam menyelesaikan permasalahan pada perencanaan pembuatan roll press.

2. Perumusan masalah

Langkah berikutnya yaitu perumusan masalah, dimana pada penelitian ini perumusan masalah merupakan hal yang penting dan mendasar dalam menentukan bahasan yang akan dilakukan pada proses mendesain dan membuat roll press, sehingga pertanyaan-pertanyaan yang diajukan dapat terjawab. 


\section{Desain alat}

Pada langkah desain alat dilakukan agar proses perencanaan baik dalam bentuk maupun ukuran yang dirancang mempunyai fungsi atau kegunaan seperti tujuan dari pembutan roll press batang rumput payung sebagai bahan material komposit.

Dari langkah desain alat ini mempunyai tujuan untuk memperbaiki proses pengerolan yang selama ini masih dilakukan secara manual seperti pada gambar 3 .

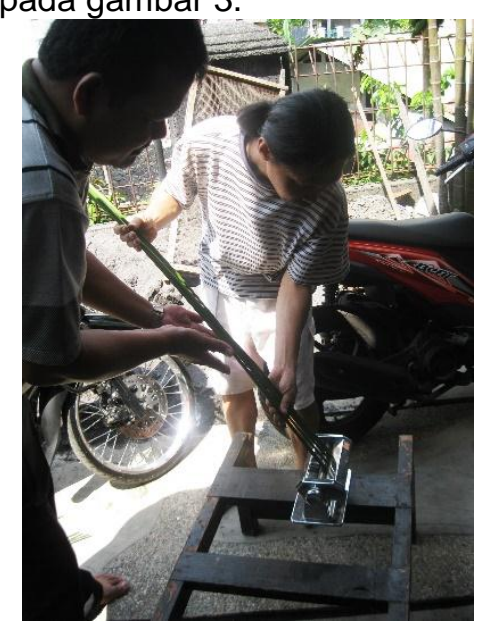

Gambar 3. Proses Pengerolan dengan cara manual

Desain alat roll press pada penelitian ini dirancang seperti gambar 4 , desain tersebut juga disesuaikan supaya operator mudah dalam mengoperasikan.

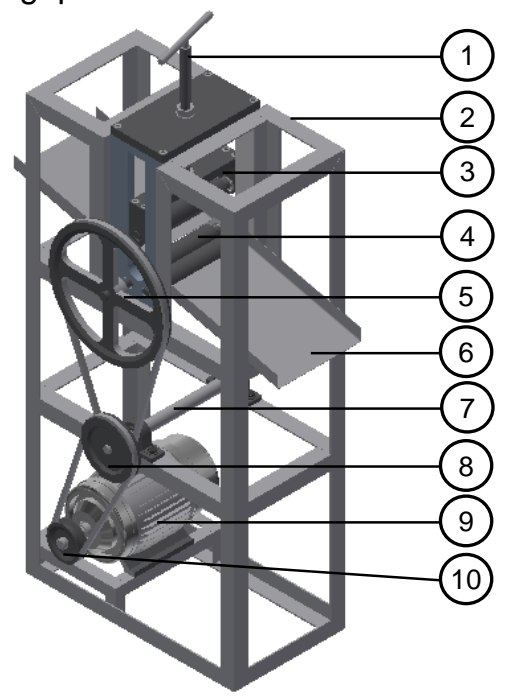

Keterangan gambar:

1. Handle penekan rol

2. Kerangka

3. Rol penekan
4. Rol penggerak

5. Pully rol penggerak

6. Corong output produk

7. Poros reduser

8. Pully reduser

9. Motor

10. Pully penggerak utama

Gambar 4. Desain Roll Press

\section{Perhitungan perencanaan}

Pada langkah perhitungan perencanaan ini untuk menentukan parameter-parameter serta bahan yang akan digunakan dalam pembutan roll press batang rumput payung, sehingga mendapatkan hasil yang optimal dalam pengepresan batang rumput payung.

5. Perhitungan perencanaan

Pada langkah perhitungan perencanaan ini untuk menentukan parameter-parameter serta bahan yang akan digunakan dalam pembutan roll press batang rumput payung, sehingga mendapatkan hasil yang optimal dalam pengepresan batang rumput payung. Perhitungan perencanaan pada pembuatan roll press antara lain perhitungan putaran, poros, sabuk dan puli, bantalan dan daya untuk memutar puli pada poros.

6. Analisa dan pembahasan

Setelah mendapatkan data-data dari hasil perhitungan, maka langkah berikutnya adalah melakukan analisa dan pembahasan untuk mengetahui hubungan bagian-bagian komponen yang dirancang telah sesuai atau belum. Jika hasil dari analisa dan pembahasan tidak sesuai maka perlu untuk dilakukan ulang proses perhitungan perencanaan. Tetapi jika hasil analisa dan pembahasan telah sesuai, maka dapat dilakukan ke tahap berikutnya.

7. Pembuatan alat

Pembuatan alat merupakan implementasi dari tahap desain dan perhitungan perencanaan. Pada langkah ini, alat roll press dibuat dengan tahapan dari menyiapkan setiap komponen-komponen yang terlibat, seperti: rangka mesin, roll press, poros, bantalan, puli dan sabuk puli. Tahap berikutnya adalah proses perakitan dengan menggunakan cara pemasangan dengan baut dan pengelasan.

8. Uji coba alat

Tahap berikutnya yaitu melakukan uji coba alat, tahap ini dilakukan untuk mengukur serta mengetahui secara teknis bahwa mesin roll press dapat berjalan dengan baik sesuai 
dengan desain dan perhitungan. Selain itu, $T=412.0,05$

untuk mengetahui hasil roll press batang

$$
=20,6 \mathrm{~N} . \mathrm{m}
$$

rumput payung dalam kapasitas, waktu dan Sedangkan kecepatan sudut putar $(\omega)$ :

kebutuhan daya.

9. Kesimpulan

$$
\omega=\frac{2 \cdot \pi \cdot n_{r}}{60}
$$

Setelah melakukan seluruh tahap desain dan perencanaan roll press, maka pada tahap terakhir adalah merangkum hasil penelitian dalam kesimpulan.

\section{Prinsip kerja alat roll press}

Setelah motor listrik dihidupkan, maka putaran dari motor listrik akan memutar puli dan belt atau sabuk akan menggerakkan puli transmisi, kemudian akan diteruskan ke Puli yang terhubung dengan salah satu poros rol. Transmisi bertingkat ini dibuat untuk menghasilkan putaran poros rol dengan putaran rendah. Tahap selanjutnya rol yang difungsikan sebagai penekan dapat diturunkan dengan cara diputar hingga menyentuh batang rumput payung yang akan dilakukan pengerolan. Dengan mekanisme seperti ini maka batang rumput payung (Cyperus Alternifolius) yang telah dipisahkan dengan daunnya siap dilakukan proses pembuatan serat komposit ke dalam mesin roll press, maka batang rumput payung akan terbentuk serat sesuai dengan dimensi nat pada poros roll press. Hasil serat yang telah di press akan keluar melewati corong output.

\section{HASIL DAN PEMBAHASAN}

\section{Perencanaan Alat}

Dalam mendesain alat roll press, maka perhitungan yang dilakukan pertama yaitu sistem transmisi. Pada perhitungan ini dihitung kebutuhan daya motor untuk penggerak utama alat roll press. Untuk menghitung kebutuhan daya, langkah awal yaitu menhitung gaya yang bekerja dengan:

$\mathrm{F}=\mathrm{m} \cdot \mathrm{a}$

Dimana: $\quad \mathrm{F}=$ Gaya yang bekerja $(\mathrm{N})$

$\mathrm{m}=$ massa roll press

$a=$ percepatan grafitasi $=9,81 \mathrm{~m} / \mathrm{s}^{2}$

dari persamaan tersebut gaya yang bekerja $137,34 \mathrm{~N}$, dan karena ada tiga rol maka gaya $\mathrm{F}_{\mathrm{t}}=412 \mathrm{~N}$.

Perhitungan torsi:

$\mathrm{T}=\mathrm{F}_{\mathrm{t}} \cdot \mathrm{d}$

Dimana:

$$
\begin{aligned}
& T=\text { Torsi }(N \cdot m) \\
& F_{t}=\text { Gaya keseluruhan }(N) \\
& D=\text { diameter roll press }=0,05 m
\end{aligned}
$$

Dimana: $\quad \omega=$ Kecepatan sudut putar $(\mathrm{rad} / \mathrm{s})$

$\mathrm{n}_{\mathrm{r}}=$ putaran reducer roll press $(\mathrm{rpm})$

maka, $\omega=\frac{2 \cdot 3,14 \cdot 159}{60}=16,64 \mathrm{rad} / \mathrm{s}$

Dari perhitungan diatas, maka dapat dihitung daya roll press yang direncanakan sebagai berikut:

$\mathrm{N}_{r}=T . \omega$

Dimana: $\mathrm{N}_{\mathrm{r}}=$ Daya roll press yang direncanakan (watt)

$\mathrm{T}=$ Torsi (N.m)

$\omega=$ Kecepatan sudut putar $(\mathrm{rad} / \mathrm{s})$

maka,

$\mathrm{N}_{r}=20,6 \cdot 16,64=342,8$ watt

Dari hasil perhitungan tersebut, maka:

$\mathrm{N}_{\mathrm{m}}=\frac{\mathrm{N}_{\mathrm{r}}}{\eta_{\mathrm{m}}}$

Dimana: $\quad \mathrm{N}_{\mathrm{m}}=$ Daya (watt)

$\mathrm{N}_{\mathrm{r}}=$ Daya roll press (watt)

$\eta_{m}=$ Efisiensi mesin penggerak $(0,95)$

$\mathrm{N}_{\mathrm{m}}=\frac{342,8}{0,95}=360,8$ watt

Dan daya motor dipilih $1 / 2 \mathrm{PK}$.

\section{Perhitungan poros roll press}

Dalam perencanaan poros roll press direncanakan panjang poros $350 \mathrm{~mm}$, sedangkan bahan poros yang digunakan direncanakan menggunakan S30C dengan kekuatan tarik yang dimiliki $48 \mathrm{~kg} / \mathrm{mm}^{2}$ atau $470,4 \mathrm{~N} / \mathrm{mm}^{2}$.

Tegangan geser sebagai berikut:

$\tau_{\mathrm{g}}=\frac{\sigma}{\mathrm{Sf}_{1} \cdot \mathrm{Sf}_{2}}$

Dimana: $\quad \tau_{\mathrm{g}}=$ Tegangan geser $\left(\mathrm{N} / \mathrm{mm}^{2}\right)$

$\sigma=$ Kekuatan tarik bahan $\left(\mathrm{N} / \mathrm{mm}^{2}\right)$

$\mathrm{Sf}_{1}=$ angka keamanan bahan

$\mathrm{Sf}_{2}=$ factor keamanan poros

Maka,

$\tau_{\mathrm{g}}=\frac{470,4}{6.3}$

$=26,1 \mathrm{~N} / \mathrm{mm}^{2}$

Sehingga diameter poros dapat dihitung sebagai berikut: 
$\mathrm{ds}=\left[\frac{5,1}{\tau \mathrm{g}} \cdot \mathrm{Kt} \cdot \mathrm{Cb} \cdot \mathrm{T}\right]^{\frac{1}{3}}$

Dimana:

$\mathrm{d}_{\mathrm{s}}=$ Diameter poros $(\mathrm{mm})$

$\mathrm{Kt}=$ Faktor koreksi $(1,0 \quad-\quad 1,5)$, digunakan 1,5

$\mathrm{Cb}=$ Faktor karena beban lentur (1,2 2,3), digunakan 1,3

$\mathrm{T}=$ Momen (kg.mm)

Dari persamaan tersebut, maka:

$$
\begin{aligned}
\mathrm{ds} & =\left[\frac{5,1}{26,1} \cdot 1,5 \cdot 1,3 \cdot 20,6\right]^{\frac{1}{3}} \\
& =19,9 \mathrm{~mm} \approx 20 \mathrm{~mm}
\end{aligned}
$$

\section{Perencanaan Transmisi}

Rasio untuk pully yang direncanakan masing-masing adalah $\boldsymbol{i}_{\mathbf{1 2}}=1,72$ dan $\boldsymbol{i}_{\mathbf{3 4}}=5,2$ agar mendapatkan putaran pada roll press $159 \mathrm{rpm}$.

$$
\frac{n_{1}}{n_{2}}=\frac{d_{2}}{d_{1}}=1,72
$$

Dimana: $\mathrm{n}_{1}=$ putaran pully motor penggerak = $1430 \mathrm{rpm}$

$\mathrm{n}_{2}=$ putaran pully motor (rpm)

$\mathrm{d}_{1}=$ diameter pully motor $=75 \mathrm{~mm}$

$\mathrm{d}_{2}=$ diameter pully reduser 1 ( $\mathrm{mm}$ )

Maka untuk menghitung diameter pully reduser 1 adalah sebagai berikut:

$$
\begin{aligned}
\mathrm{d}_{2} & =\mathrm{d}_{1} \cdot 1,72 \\
& =75 \cdot 1,72 \\
& =129 \mathrm{~mm}
\end{aligned}
$$

Sedangkan putaran pada poros reduser:

$$
\begin{aligned}
& \mathrm{n}_{1}=\mathrm{n}_{2} \cdot 1,72 \\
& \mathrm{n}_{2}=1430 / 1,72=831,4 \approx 831 \mathrm{rpm}
\end{aligned}
$$

Untuk menentukan diameter pully yang menggerakkan roll press, maka dapat dihitung dengan menggunakan persamaan:

Dimana:

$$
\frac{n_{3}}{n_{4}}=\frac{d_{4}}{d_{3}}=5,2
$$

$\mathrm{n}_{3}=$ putaran pully reduser $2=$ putaran pully

$$
\text { reduser } 1=831 \mathrm{rpm}
$$

n4 = putaran pully motor penggerak (rpm)

d3 $=$ diameter pully reduser $2=59 \mathrm{~mm}$

$\mathrm{d} 4=$ diameter roll pully $(\mathrm{mm})$

Maka untuk menghitung diameter pully reduser $2\left(\mathrm{~d}_{4}\right)$ adalah sebagai berikut:

$$
\begin{aligned}
\mathrm{d}_{4} & =\mathrm{d}_{3} \cdot 5,2 \\
& =59 \cdot 5,2 \\
& =306,8 \mathrm{~mm} \approx 307 \mathrm{~mm}
\end{aligned}
$$

Sedangkan putaran pada poros rol penggerak:

$$
\begin{aligned}
& \mathrm{n}_{3}=\mathrm{n}_{4} \cdot 5,2 \\
& \mathrm{n}_{4}=831 / 5,2=159,8 \approx 160 \mathrm{rpm}
\end{aligned}
$$

\section{Perhitungan Bantalan}

Pada perencanaan ini, jenis bantalan yang digunakan adalah bantalan gelinding. Penggunaan bantalan gelinding supaya dapat menerima beban radial yang tegak lurus dengan sumbu poros. Perhitungan bantalan adalah sebagai berikut:

1. Momen geser bantalan

$$
M=F . f .(D / 2)
$$

\section{Dimana:}

$\mathrm{M}=$ Momen geser bantalan (N.mm)

$\mathrm{F}=$ Gaya radial $(\mathrm{N})$

$f=$ Koefisien geser bantalan $=0,0015$ untu bola bantalan tunggal

$\mathrm{D}=$ Diameter poros $(\mathrm{mm})$

Maka,

$M=20,6$. 0,0015 . (20/2)

$$
=0,309 \text { N.mm }
$$

2. Gaya Tangensial

$F_{t}=\frac{2 \cdot \mathrm{T}}{d_{s}}$

Dimana:

$\mathrm{Ft}=$ Gaya Tangensial $(\mathrm{N})$

$\mathrm{T}=$ Torsi (N.mm)

ds $=$ diameter $(\mathrm{mm})$

$F_{t}=\frac{2 \cdot 20,6}{20}=2,06 \mathrm{~N}$

\section{Proses Pembuatan dan Perakitan Roll Press}

Proses pembuatan komponen-komponen roll press batang rumput payung diawali dari menyiapkan bahan baku yang dibutuhkan.

a. Kerangka Roll Press

Kerangka roll press dibuat dari besi siku profile L 50x50mm dengan ketebalan $5 \mathrm{~mm}$. Bahan baku kerangka dipotong dengan menyesuaikan kebutuhan ukuran sesuai dengan gambar kerja, kebutuhan pemotongan ukuran tiap bagian seperti berikut:

Tabel 1. Kebutuhan komponen kerangka roll press 


\begin{tabular}{|c|l|c|c|l|}
\hline No & \multicolumn{1}{|c|}{$\begin{array}{l}\text { Ukuran } \\
\text { Panjang }\end{array}$} & Jml & Satuan & Keterangan \\
\hline 1 & $\begin{array}{l}\text { Ukuran } \\
\text { panjang } \\
1200 \mathrm{~mm}\end{array}$ & 4 & pcs & $\begin{array}{l}\text { Untuk bagian } \\
\text { pilar utama }\end{array}$ \\
\hline 2 & $\begin{array}{l}\text { Ukuran } \\
\text { panjang 520 } \\
\text { mm }\end{array}$ & 6 & pcs & $\begin{array}{l}\text { Bagian } \\
\text { depan }\end{array}$ \\
\hline 3 & $\begin{array}{l}\text { Ukuran } \\
\text { panjang 240 } \\
\text { mm }\end{array}$ & 6 & pcs & $\begin{array}{l}\text { Bagian } \\
\text { samping }\end{array}$ \\
\hline 4 & $\begin{array}{l}\text { Ukuran } \\
\text { Panjang 400 } \\
\text { mm }\end{array}$ & 4 & pcs & Bagian atas \\
\hline 5 & $\begin{array}{l}\text { Ukuran } \\
\text { Panjang 145 } \\
\text { mm }\end{array}$ & 8 & pcs & Bagian atas \\
\hline
\end{tabular}

Setelah komponen-komponen kerangka roll press dipotong sesuai ukuran, maka tahap berikutnya akan dirakit dengan sistem permanen yaitu dengan proses pengelasan. Hasil perakitan komponen kerangka roll press seperti gambar berikut.
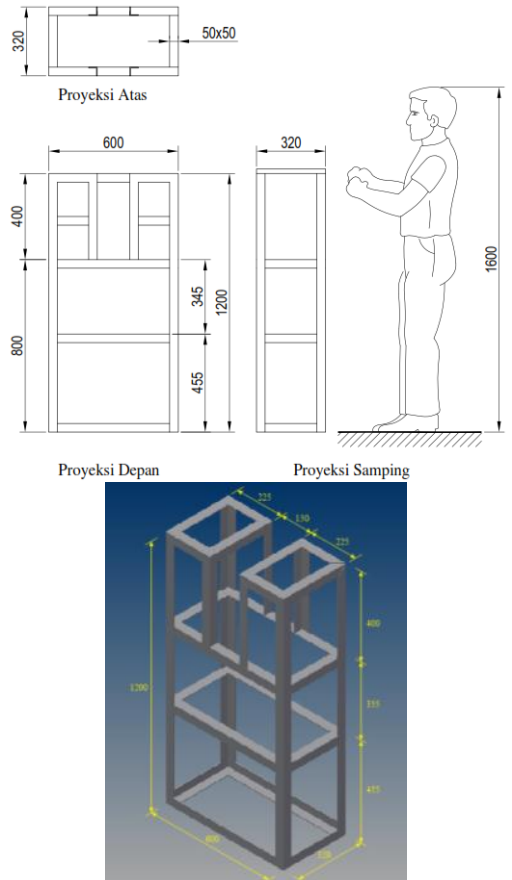

Gambar 5. Kerangka Roll Press

\section{b. Roll Press}

Bagian dari kelompok roll press seperti dapat dilihat dari gambar 6 terdiri dari beberapa bagian komponen pendukung, antara lain handle penekan, roll press, bantalan dan plat penyangga.

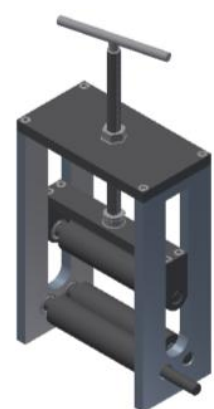

Gambar 6. Roll Press

Bagian komponen dari roll press dapat dilihat pada gambar berikut:

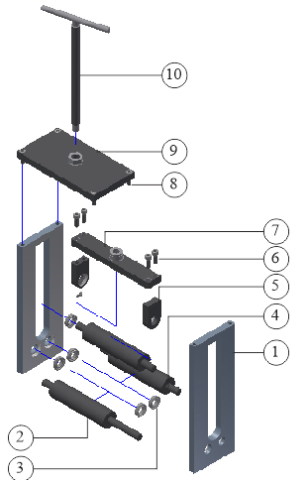

Keterangan gambar:

1. Plat penyangga utama roll press

2. Roll press penggerak

3. Bantalan

4. Roll press bawah

5. Tempat bantalan rol poros penekan

6. Baut M10

7. Plat penekan

8. Baut M12

9. Plat utama bagian atas

10. Handle pengatur penekanan roll press

\section{Gambar 7 Proses Perakitan Roll Press}

c. Pemasangan Komponen Sistem Penggerak

Tahapan berikutnya adalah memasang komponen sistem penggerak roll press, antara lain adalah motor penggerak, pully motor penggerak, poros reduser, pully reduser, sabuk belt motor penggerak, pully rol pres dan sabuk belt reduser ke pully rol pres. Adapun proses pemasangannya dapat dilihat seperti pada gambar berikut:

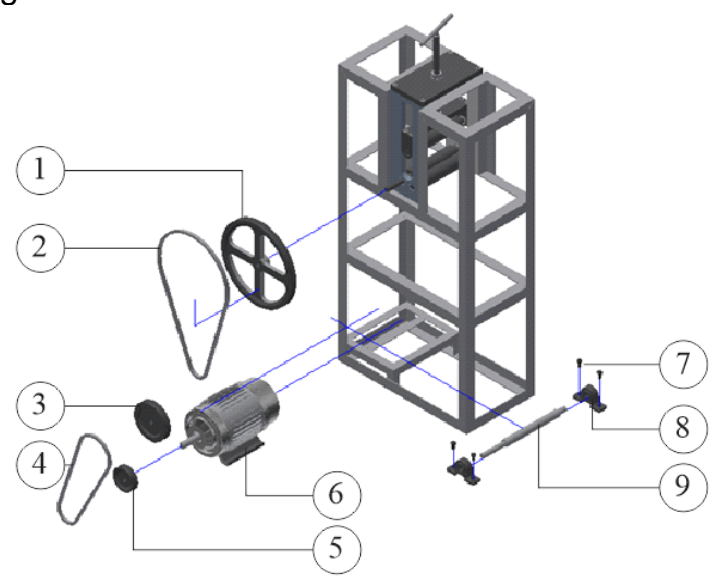


Keterangan gambar

1. Pully penggerak roll press

2. Sabuk Belt Roll press

3. Pully reduser

4. Sabuk belt motor penggerak

5. Pully motor penggerak

6. Motor penggerak $1 / 2 \mathrm{PK}$

7. Baut M12

8. Bantalan

9. Poros reduser

\section{Gambar 8. Proses Pemasangan Komponen Sistem Penggerak}

\section{Pengujian Roll Press dan Hasil Pengerolan}

Pengujian alat roll press batang rumput payung sebagai bahan baku material komposit dilakukan dengan dua proses pengujian, yaitu proses pengerolan batang rumput payung yang diuji dari proses variasi gaya penekanan rol terhadap batang rumput payung dan prses variasi putaran putar rol terhadap pengerolan batang rumput payung.

a. Pengujian roll press batang rumput payung terhadap variasi gaya pembebanan

Pada pengujian alat roll press batang rumput payung terhadap variasi gaya pembebanan, peneliti mengambil tiga variasi gaya pembebanan dengan tujuan untuk mengetahui perbedaan dan hasil yang lebih baik. Tiga variasi gaya pembebanan yang digunakan adalah $10 \mathrm{~kg}, 12 \mathrm{~kg}$ dan $14 \mathrm{~kg}$. Hasil pengujian dengan variasi gaya pembebanan adalah pada tabel 2 .

Tabel 2. Hasil Pengujian variasi gaya pembebanan

\begin{tabular}{|c|c|c|c|c|c|c|}
\hline $\begin{array}{c}\text { Variasi } \\
\begin{array}{c}\text { Pembe } \\
\text { banan } \\
(\mathrm{kg})\end{array}\end{array}$ & $\begin{array}{c}\text { Rata- } \\
\text { rata } \\
\text { Keteb } \\
\text { alan } \\
\text { Awal } \\
(\mathrm{mm})\end{array}$ & $\begin{array}{c}\text { Rata- } \\
\text { rata } \\
\text { Keteb } \\
\text { alan } \\
\text { Akhir } \\
(\mathrm{mm})\end{array}$ & $\begin{array}{c}\text { Selisi } \\
\mathrm{h} \\
\text { Teba } \\
\text { I } \\
(\mathrm{mm})\end{array}$ & $\begin{array}{c}\text { Rata- } \\
\text { rata } \\
\text { Berat } \\
\text { Awal } \\
\text { (gra } \\
\mathrm{m})\end{array}$ & $\begin{array}{c}\text { Rata- } \\
\text { rata } \\
\text { Berat } \\
\text { Akhir } \\
\text { (gra } \\
\mathrm{m})\end{array}$ & $\begin{array}{c}\text { Selisih } \\
\text { Berat } \\
(\mathrm{gram})\end{array}$ \\
\hline 10 & 0,73 & 0,33 & $\begin{array}{c}0,4 \\
0\end{array}$ & 10,50 & 10,23 & $\begin{array}{c}0,2 \\
7\end{array}$ \\
\hline 12 & 0,72 & 0,20 & $\begin{array}{c}0,5 \\
2\end{array}$ & 10,60 & 10,30 & $\begin{array}{c}0,3 \\
0\end{array}$ \\
\hline 14 & 0,78 & 0,21 & $\begin{array}{c}0,5 \\
7\end{array}$ & 10,57 & 10,20 & $\begin{array}{c}0,3 \\
7\end{array}$ \\
\hline
\end{tabular}

Data di atas menjelaskan bahwa semakin besar/berat gaya pembebanan, maka semakin besar pula penyusutan (pengurangan berat) akibat berkurangnya kadar air. Selain itu pembebanan yang diberikan juga sangat memengaruhi ketebalan batang rumput payung setelah dilakukan proses pengerolan.
Secara visual hasil pengerolan dengan variasi gaya pembebanan terhadap rumput payung (cyperus alternifolius) terlihat seperti pada gambar berikut:

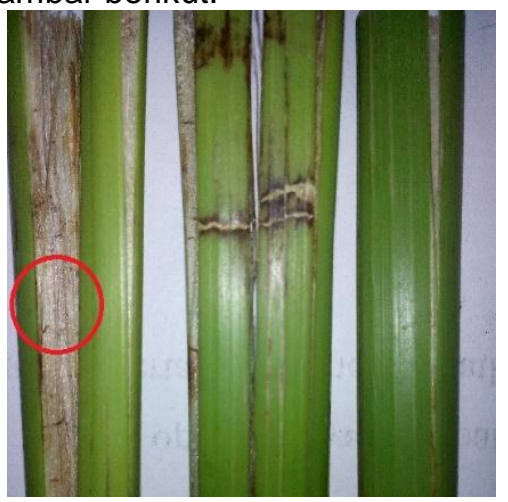

(a) Pembebanan $10 \mathrm{~kg}$

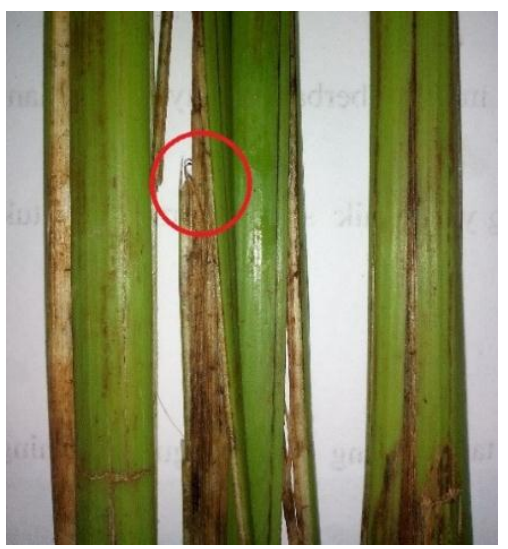

(b) Pembebanan $12 \mathrm{~kg}$

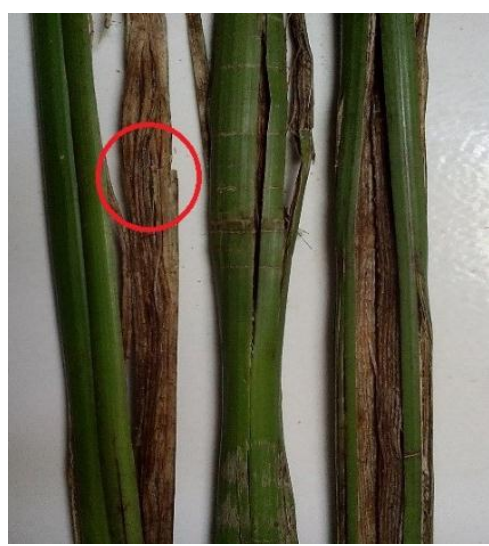

(c) Pembebanan $14 \mathrm{~kg}$

Gambar 9. Hasil Pengerollan Mesin Roll Press Rancang Bangun Dengan Variasi Pembebanan

Dari Gambar 9, mengartikan bahwa gambar yang diberi tanda lingkaran merah: (a) 
menunjukkan bahwa pada variasi pembebanan sebesar $10 \mathrm{~kg}$ tidak terjadi perpatahan. Sedangkan pada gambar (b) dengan variasi pembebanan sebesar $12 \mathrm{~kg}$ terjadi perpatahan tapi perpatahan pada serat batang rumput payung tidak terlalu banyak (sedang) dan pada gambar (c) Pembebanan $14 \mathrm{~kg}$ terjadi perpatahan yang banyak.

b. Pengujian roll press batang rumput payung terhadap variasi Putaran

Pada pengujian alat roll press batang rumput payung terhadap variasi putaran, peneliti mengambil tiga variasi putaran dengan tujuan untuk mengetahui perbedaan dan hasil yang lebih baik. Tiga variasi putaran yang digunakan adalah $160 \mathrm{rpm}, 197 \mathrm{rpm}$ dan 280 rpm. Hasil pengujian dengan variasi putaran adalah pada tabel 3.

Tabel 3. Hasil pengujian variasi putaran

\begin{tabular}{|c|c|c|c|c|c|c|}
\hline $\begin{array}{c}\text { Varia } \\
\text { si } \\
\text { Putar } \\
\text { an } \\
\text { (rpm) }\end{array}$ & $\begin{array}{c}\text { Rata- } \\
\text { rata } \\
\text { Keteba } \\
\text { lan } \\
\text { Awal } \\
(\mathrm{mm})\end{array}$ & $\begin{array}{c}\text { Rata- } \\
\text { rata }\end{array}$ \\
$\begin{array}{c}\text { Keteb } \\
\text { alan } \\
\text { Akhir } \\
(\mathrm{mm})\end{array}$ & $\begin{array}{c}\text { Selisi } \\
\text { h } \\
\text { Tebal } \\
(\mathrm{mm})\end{array}$ & $\begin{array}{c}\text { Rata- } \\
\text { rata } \\
\text { Berat } \\
\text { Awal } \\
\text { (gram) }\end{array}$ & $\begin{array}{c}\text { Rata- } \\
\text { rata } \\
\text { Berat } \\
\text { Akhir } \\
(\mathrm{gram})\end{array}$ & $\begin{array}{c}\text { Selisih } \\
\text { Berat } \\
\text { (gram) }\end{array}$ \\
\hline 197 & 0,7 & $\begin{array}{c}0,10 \\
0\end{array}$ & 0,6 & 13,50 & 2,3 & 11,20 \\
\hline 280 & 0,7 & $\begin{array}{c}0,09 \\
8\end{array}$ & 0,6 & 13,50 & 2,97 & 10,53 \\
\hline & 0,09 & 0,6 & 13,50 & 3,0 & 10,50 \\
\hline
\end{tabular}

\section{KESIMPULAN}

Dari hasil penelitian ini dapat disimpulkan:

1. Rancangan alat roll press batang rumput payung yang telah di desain dan di buat memberikan kemudahan dalam proses menyiapkan serat sebagai bahan baku komposit.

2. Dalam perhitungan pembuatan roll press batang rumput payung didapatkan putaran rendah yang ideal untuk pengoperasiannya dengan putaran 160 rpm dan gaya pembebanan $10 \mathrm{~kg}$ yang menghasilkan serat rumput payung tidak mengalami perpatahan.

3. Berdasarkan hasil pengujian dengan variasi gaya pembebanan $10 \mathrm{~kg}, 12 \mathrm{~kg}$ dan $14 \mathrm{~kg}$, secara berurutan dihasilkan berat rata-rata untuk sampel yang diambil adalah 0.27 gram, 0.30 gram dan 0.37 gram.

4. Berdasarkan hasil pengujian dengan variasi putaran $160 \mathrm{rpm}, 197 \mathrm{rpm}$ dan $280 \mathrm{rpm}$, secara berurutan dihasilkan berat rata-rata untuk sampel yang diambil adalah 11.20 gram, 10.53 gram dan 10.50 gram.

\section{DAFTAR PUSTAKA}

[1] Anggraini, 2011, Pengolahan air limbah domestic dengan lahan basah buatan menggunakan rumput payung (Cyperus Alterniofolius), Skripsi UPN Veteran Jawa Timur.

[2] Deutschman, Aaron D., 1975, Machine Design: Theory and Practice. New York: Macmillan Publishing Co, Inc.

[3] Lei, H. F., Zhang, Z. Q., \& Liu, B. (2012). Effect of fiber arrangement on mechanical properties of short fiber reinforced composites. Composites Science and Technology, 72(4), 506-514. doi:10.1016/j.compscitech.2011.12.011.

[4] Madsen,B.,\&Lilholt, H.2003. Physicaland mechanicalproperties ofunidirectional plant fibrecomposites-an evaluationof theinfluenceof porosity. Composites Science and Technology,63(9), 12651272.doi:10.1016/S0266-3538(03)000976.

[5] Sularso, Suga K., 1994. Dasar Perencanaan dan Pemilihan Elemen Mesin, Pradya Paramita Jakarta.

[6] Shygley, Joseph E, 1986. Perencanaan Teknik Mesin jilid 1 \& 2, Erlangga, Jakarta.

[7] Sato, G. Takeshi, 2000. Menggambar Mesin Menurut Standar ISO, Cetakan ke9, PT. Pradya Paramita. Jakarta. 